\title{
Pilar-pilar Keunggulan Kompetitif: Sebuah Pandangan Berbasis Sumber Daya (Competitive Advantage Pillars: a View Based Resource)
}

\author{
Dede Hertina $^{1 *}$, Mohamad Bayu Herdiawan Hidayat ${ }^{2}$ \\ ${ }^{1}$ Universitas Widyatama, Bandung, Indonesia, ${ }^{2}$ Universitas Telkom Bandung, Bandung, Indonesia
}

The purpose of this study is to develop a general model of resources and company performance and to build consensus for saving models to see economic activities that underlie a resource-based view of competitive advantage and integrate existing perspectives into a model savings on resources and company performance. The essence of this model are the four conditions that underlie sustainable competitive advantage, all of which must be met. These include superior resources (heterogeneity in an industry), ex post limits to competition, imperfections in resource mobility, and limits before competition (ex ante limits to competition). In the concluding section, application models are discussed both for single business strategies and corporate strategies.

Keywords: Resource Based View, Competitive Advantage

Tujuan penelitian ini untuk mengembangkan model umum dari sumber daya dan kinerja perusahaan dan untuk membangun konsensus untuk penghematan model untuk melihat kegiatan ekonomi yang mendasari pandangan berbasis sumber daya (resource based view) dari keunggulan kompetitif (competitive advantage) dan mengintegrasikan perspektif yang ada menjadi sebuah model penghematan dari sumber daya dan kinerja perusahaan. Inti dari model ini adalah empat kondisi yang mendasari keunggulan kompetitif (competitive advantage) yang berkelanjutan, yang semuanya harus dipenuhi. Hal ini termasuk sumber daya unggul (heterogenitas dalam suatu industri), batasan sesudah bersaing (ex post limits to competition), ketidak sempurnaan dalam mobilitas sum-

OPEN ACCESS ISSN 2503-3077 (Online) (online) ISSN 2503-3077 (print)

${ }^{*}$ Correspondence: Dede Hertina dede

Received: 21 August 2019 Accepted: 21 September 2019 Published: 30 October 2019

Citation:

Hertina D and Hidayat MBH (2019) Pilar-pilar Keunggulan Kompetitif: Sebuah Pandangan Berbasis

Sumber Daya (Competitive Advantage Pillars: a View Based Resource).

Perisai : Islamic Banking and Finance Journal. 3:2. doi: 10.21070/perisai.v3i2.2623 ber daya, dan batasan sebelum bersaing (ex ante limits to competition). Pada bagian penutup, dibahas aplikasi model baik untuk strategi bisnis tunggal dan strategi perusahaan.

Kata Kunci: Tampilan Berbasis Sumber Daya, Keunggulan Kompetitif 


\section{PENDAHULUAN}

Dalam beberapa tahun terakhir telah mulai muncul sebuah model bidang manajemen strategis yang unik bagaimana perusahaan berkompetisi. Dikenal sebagai "Resource Based View ", model ini dipandang memiliki potensi penting sebagai paradigma untuk bidang manajemen stratejik. Sementara lainnya bertanya-tanya apakah model ini memberikan banyak tambahan wawasan atas pemahaman tradisional. Diakui, kerja dengan berbasis sumber daya yang konsisten dan telah mengakar dalam tradisi penelitian di bidang kebijakan. Gagasan bahwa perusahaan pada dasarnya heterogen, dalam hal sumber daya dan kemampuan internal- nya, telah lama berada di jantung bidang manajemen stratejik. Pendekatan klasik dalam perumusan strategi, misalnya, dimulai dengan penilaian kompetensi organisasi dan sumber daya Andrews (1971). Mereka yang relatif berbeda atau unggul dibandingkan pesaing, dapat menjadi dasar untuk kompetitif, dapat menjadi dasar bagi keunggulan kompetitif jika mereka cocok dengan peluang lingkungan yang tepat (Andrews (1971); Thompson and Strickland (1990))

Pinsip dasar yang terus menerus dikembangkan dalam penelitian berbasis sumber daya, sedangkan model masih dalam tahap perngembangan, hal ini telah memperdalam topik-topik tentang penerapan sumber daya dan dikombinasikan, keunggulan kompetitif berkelanjutan, sifat dasar dari harga, dan asal-usul heterogenitas. Penrose (1959) telah menganggap sebagai sesuatu yang sangat kuat pengaruhnya. Kontribusi lainnya yang tekenal termasuk Lippman and Rumelt (1982), Teece (1980a), Teece (1982a), Nelson and Winter (1982), Rumelt (1984a), Rumelt (1987a), Wernerfelt (1984a), Barney (1986), Barney (1991), Dierickx and Cool (1989), dan Castanias and Helfat (1991), Connor (1991), dan Mahoney and Pandian (1992). Aliran penelitian ini merupakan salah satu yang mengesankan. Dan sementara banyak yang setuju bahwa ada kebutuhan untuk kekakuan yang lebih besar dan pendalaman yang lebuh detail, pekerjaan yang telah dilakukan memberikan pondasi dan inspirasi yang kuat bagi pekerjaan yang akan datang.

Pada bagian pertama, model berbasis sumber daya (resource based model) dari kondisi teoritis yang mendasari keunggulan kompetitif disajikan. Terdapat empat kondisi, kesemuanya harus penuhi. Pertama adalah heterogenitas sumber daya, yang berasal dari Ricardian atau harga monopoli (monopoly rent). Batasan sesudah persaingan diperlukan untuk mempertahankan harga sewa. Ketidak sempurnaan mobilitas sumber daya memastikan bahwa sewa terikat untuk perusahaan dan berbagi. Batasan sebelum persaingan untuk mencegah persaingan biaya dari mengimbangi sewa. Masing-masing kondisi dijelaskan pada gilirannya. Model ini dimaksudkan untuk membantu secara teoritis pemahaman kinerja perusahaan yang unggul serta untuk menginformasikan praktik manajemen. Pada bagian akhir, beberapa aplikasi dan implikasi dari model dijelaskan. Khususnya, penerapan bekerja berbasis sumber daya untuk single-strategi bisnis, serta strategi multibisnis perusahaan, kesemua bentuk didiskusikan.

\section{Model Keunggulan Kompetitif (A Model of Competitive Advantage) Heterogenitas}

Sebuah asumsi dasar pekerjaan berbasis sumber daya adalah bahwa serangkaian sumber daya dan kemampuan yang mendasari produksi adalah heterogenitas di perusahaan Barney (1991). Salah satu mungkin menggambarkan faktor produktivitas digunakan untuk nilai instrinsik dari perbedaan tingkat efisiensi. beberapa lebih baik dari yang lain. Perusahaan diberkahi dengan sumber daya yang mampu menghasilkan lebih ekonomis dan/ atau lebih baik memuaskan apa yang pelanggan inginkan. Heterogenitas menyiratkan bahwa perusahaan dari berbagai kemampuan yang mampu bersaing di pasar dan, setidaknya akan impas. Perusahaan dengan sumber daya marginal hanya dapat berharap untuk mencapai titik impas (breakeven). Perusahaan-perusahaan dengan sumber daya yang unggul akan mendapatkan penghasilan.

\section{Ricardian Rents}

Heterogenitas dalam suatu industri dapat mencerminkan adanya faktor keunggulan produktif yang berada dalam keterbatasan penawaran. Itu semua mungkin faktor tetap yang tidak dapat diperluas. Lebih sering, hal tersebut adalah faktor yang semi tetap, dalam arti bahwa pasokan faktor tersebut tidak bias akan berkembang pesat. Faktor yang langka dalam arti bahwa faktor tersebut tidak cukup untuk memuaskan permintaan atas layanan yang diberikana. Dengan demikian, sumber daya yang rendah terbawa ke dalam produksi juga. Hal ini merupakan argumen Ricardian yang dikenal. Argument tersebut dapat dipahami secara jelas dengan mengasumsikan bahwa perusahaan dengan sumber daya yang unggul memiliki lebih rendah Biaya rata-rata dari firms lainnya (Gambar 1 ) Perusahaan- perusahaan dengan biaya rendah ini memiliki kurva penawaran tidak elastis (inelastic), dalam hal itu perusahaan tidak dapat meningkatkan output secara cepat, terlepas dari seberapa tinggi harga yang mungkin akan terjadi. Harga yang tinggi, bagaimanapun juga penyebab lainnya perusahaan yang kurang efisien untuk memasuki industri. Seperti perusahaan akan memasuki dan menghasilkan asalkan harga melebihi biaya marjinal (marginal cost-MC). Dalam kesetimbangan, permintaan dan penawaran industri adalah dalam keseimbangan, biaya tinggi bagi perusahaan akan impas $(\mathrm{P}=$ $\mathrm{AC})$, dan biaya rendah bagi perusahaan akan mendapatkan keuntungan yang lebih dari biasanya dalam bentuk penghasilan untuk sumber daya mereka yang langka $(\mathrm{P}>\mathrm{AC})$.

\section{[Figure 1 about here.]}

\section{[Figure 2 about here.]}

Model ini konsisten dengan perilaku kompetitif di pasar produk. Perusahaan yang menetapkan harga dan menghasilkan pada titik di mana harga sama dengan biaya marjinal. Tingginya keuntungan dari perusahaan yang efisien tidak dapat dikaitkan dengan suatu keterbatasan dari output yang dihasilkan atau kekuatan pasar. Hal tersebut, juga tidak tergantung pada keunikan atau bahkan kelangkaan dalam arti absolut. Secara teori kemungkinan keuntungan yang akan diterima melalui sejumlah produsen sama dalam efisiensinya, asalkan 
perbedaan efisiensi tetap antara produsen dan produsen lainnya produsen. Apa yang terpenting adalah bahwa sumber daya yang unggul masih terbatas penawarannya. Dengan demikian, efisien perusahaan dapat mempertahankan jenis keunggulan kompetitifnya hanya jika sumber daya mereka tidak dapat diperluas secara bebas atau ditiru oleh perusahaan lain.

Penambahan produksi akibat dari peningkatan efisiensi oleh produsen akan menggeser kurva penawaran keluar. Hal ini akan menurunkan harga keseimbangan, memaksa perusahaan untuk meninggalkan pasar. Perusahaan yang tersisa akan menghasilkan pada titik di mana Harga sama dengan biaya marjinal ( marginal cost) dan biaya rata-rata ( average cost ). Akibatnya, pendapatan akan hilang dan hanya pendapatan normal yang akan diperoleh melalui efisien para produsennya.

Model Ricardian sering dianggap dengan menghargai pada sumber daya yang sangat tetap dalam penawaran. Tapi hal itu dapat diterapkan juga untuk sumber daya semi tetap, yang mana lebih besar tingkat kepentingannya. Sumber daya ini yang sementara terbatas dalam jangka pendek, dapat diperpanjang dan diperluas secara bertahap dalam perusahaan yang memanfaatkannya. Pemanfaatan sumber daya tersebut mungkin sebenarnya meningkatkan pendapatan. Prahalad and Hamel (1990) menjelaskan bagaimana inti kompetensi ( core competency), terutama yang melibatkan pembelajaran bersama ( collective learning ) dan berbasis pengetahuan ( knowledge based ), ditingkatkan seperti yang diterapkan. Seperti sumber daya mungkindapat menyediakan baik dasar dan arah guna pertumbuhan perusahaan itu sendiri. Misalnya, mungkin ada masalah mendasar yang tertanam dalam perusahaan berbasis pengetahuan ( knowledge based). Kemampuan saat ini mungkin baik mendorong dan membatasi pembelajaran masa depan dan aktivitas investasi. Pertumbuhan incremental dan pembaharuan sumber daya yang terbatas seperti itu, bagaimanapun juga tidak konsisten dengan pandangan Ricardian atas pendapatan dan keunggulan kompetitif.

\section{Monopoly Rent}

Kondisi heterogenitas setara dengan konsisten model kekuatan pasar dan harga monopoli ( monopoly rent) seperti halnya yang dikemukakan Ricardian. Perbedaan keuntungan monopoli dari Ricardian rent adalah bahwa hasil keuntungan monopoli dari pembatasan output yang disengaja dibandingkan dengan kelangkaan penawaran sumber daya yang melekat. Dalam model monopoli, heterogenitas dapat dihasilkan dari kompetisi spasial atau diferensiasi produk. Hal ini mungkin mencerminkan keunikan dan lokalisasi monopoli. Kemungkinan karena adanya intra- industri yang memobilitasi hambatan yang membedakan kelompok perusahaan satu dengan yang lain Caves and Porter (1977) Ini mungkin menuntut ukuran keuntungan dan komitmen yang tidak bias diubah atau keuntungan penggerak pertama.. Ada banyak model-model lainnya, seperti. Kesemuanya meiliki kesamaan anggapan bahwa perusahaan bahwa perusahaan dalam posisi menguntungkan menghadapi kurva permintaan miring ke bawah. Perusahaanperusahaan ini kemudian memaksimalkan laba dengan membatasi secara relatif output mereka ke tingkat yang kompetitif. Hal ini disebut model kekuatan pasar. Tidak seperti modelmodel Ricardian, banyak yang strategis dalam perusahaan dengan memperhitungkan perilaku dan posisi relative dari saingan mereka. Perusahaan yang homogen juga bisa mendapatkan harga monopoli ( monopoly rent). Perilaku Cournot ditunjukkan oleh pesaing yang identik, misalnya, dapat menghasilkan harga di atas biaya marjinal ( marginal cost ). Tetapi jenis perilaku ini yang difasilitasi oleh beberapa dan karena itu sangat tergantung pada hambatan untuk memasukinya. Asimetri harus ada antara kewajiban perusahaan dan pendatang potensial. Dalam hal ini, heterogenitas terjadi di kedua kelompok perusahaan.

\section{Ex post limits to competition}

Keberkelanjutan keunggulan kompetitif mensyaratkan bahwa kondisi heterogenitas dipertahankan. Jika heterogenitas adalah fenomena singkat, harga juga akan cepat berlalu. Strategi terutama berkaitan dengan harga selama jangka panjang yang kondisi heterogenitas harus relative tahan lama untuk menambah nilai. Hal ini hanya akan menjadi kasus jika ada dalam ex post limits to competition juga. Dengan ini berarti bahwa setelah harga sebuah perusahaan mendapatkan posisi yang unggul dan produktif, harus ada kekuatan yang membatasi kompetisi bagi harga mereka. Kompetisi dapat menghilang harga dengan meningkatkan penawaran sumber daya yang langka. Alternatifnya, mungkin mencoba melemahkan untuk membatasi output monopolis ( atau oligopolis ). Gambar 2 menggambarkan bagaimana ex post competition membuat kurva penawaran industri yang lebih elastis dan membantah Ricardian rent. Ex post competition membantah harga monopoli ( monopoly rent ) juga, dengan meningkatkan output atau dengan membuat kurva permintaan individu lebih elastis.

\section{Resouce based work difokuskan pada dua faktor-faktor kritis yang membatasi ex post competition}

Penggantian mengurangi harga dengan membuat kurva permintaan dari monopolis atau oligopolies lebih elastis. Hal ini adalah salah satu " lima kekuatan" klasik dari Porter (1980). " Perhatian yang lebih besar, bagaimanapun, telah diberikan dengan kondisi ketidak sempurna kemampuan meniru. Rumelt (1984b) berpendapat istilah “ isolating mechanism " untuk merujuk kepada fenomena yang melindungi individu perusahaan dari tiruan dan mempertahankan harga mereka naik. Hal ini termasuk hak kepemilikan ( property right ) untuk sumber daya langka dan berbagai hak quasi dalam bentuk kelambanan, asimetri informasi, dan friksi yang menghambat persaingan imitative Rumelt (1987a) . Yang menarik adalah gagasan ambiguitas kausal Lippman and Rumelt (1982). Hal ini mengacu pada ketidakpastian mengenai penyebab perbedaan efisiensi antara perusahaan-perusahaan. Ambiguitas kausal mencegah dari calon imitator untuk mengetahui secara pasti tentang apa yang ditiru atau bagaimana menirunya. Ditambah dengan biaya nonrecoverable ( nonrecoverable costs ), ketidakpastian tersebut dapat membatasi aktivitas imitatif, sehingga mempertahankan kondisi heterogenitas. Isolating mechanism lainnya termasuk pembelajaran produser, biaya perpindahan pembeli, reputasi, biaya pencarian pembeli, banyak saluran, dan skala ekonomi ketika aset khusus diperlukan Rumelt (1987b). Rumelt (1984a) menjelaskan isolating mechanism sebagai analog dari Caves and 
Porter (1977) hambatan mobilitas, yang dengan sendirinya merupakan perpanjangan dari Bain (1956) Bain (1956) konsep entry barrier. Hambatan mobilitas, bagaimanapun, berfungsi untuk mengisolasi kelompok perusahaan sejenis dalam industri yang heterogen, sementara entry barrier mengisolasi peserta industri dari pendatang potensial. Yao (1988) telah menyaring serangkaian faktor yang lebih mendasar daripada daftar entry barrier yang disarankan oleh Porter (1980) dan Bain (1956). Dia berpendapat bahwa kegagalan pasar yang kompetitif adalah karena lebih fundamental bagi produksi yang ekonomis dan sunk cost, biaya transaksi, dan ketidak sempurnaan Informasi. Ghemawat (1986) menyarankan kategorisasi yang berbeda, dengan lebih dari orientasi pasar suatu perusahaan. Dia berpendapat bahwa posisi imitasi berasal dari ukuran keuntungan, akses yang lebih disukai baik untuk sumber daya maupun pelanggan, dan/atau pembatasan pada pilihan pesaing. Dierickx and Cool (1989) menawarkan perspektif yang unik tentang topik batas imitasi. Mereka fokus pada faktor-faktor yang mencegah imitasi yang berharga akan tetapi aset saham yang tidak dapat menghasilkan ( nontradeable ). Mereka mempertahankan bahwa bagaimana imitable aset adalah tergantung pada sifat dari proses dengan yang terakumulasi. Mereka mengidentifikasi karakteristik berikut sebagai penyajian untuk menghambat imitasi : time compression diseconomies, asset mass efficiencies, interconnectedness of asset stocks, asset erosion, dan causal ambiguity.

Tulisan Dierickx and Cool (1989) adalah bagian pekerjaan yang sangat penting karena berfokus pada macam-macam sumber daya dan kemampuan yang menjadi pusat perhatian untuk teori resource based : nontradeable asset yang berkembang dan menumpuk di dalam perusahaan. Aset tersebut cenderung menentang imitasi karena asset tersebut memiliki dimensi yang kuat diam-diam dan kompleks secara sosial. Aset tersebut lahir dari keterampilan organisasi dan pembelajaran perusahaan. Perkembangan asset tersebut adalah bagian dari ketergantungan dalam arti bahwa hal itu bergantung pada tingkat pembelajaran sebelumnya, investasi, asset saham, dan kegiatan pengembangan. Barangkali calon -imitator digagalkan oleh oleh kesulitan menemukan dan mengulangi proses perkembangan dan sangat terlambat dalam keterlibatannya. Yang penting, aset ini juga bergerak dan terikat dengan perusahaan. Faktor imobilitas, atau ketidak sempurnaan mobilitas adalah persyaratan kunci lainnya untuk keuntungan yang berkelanjutan.

\section{Imperfect mobility}

Sumber daya secara sempurna bergerak jika mereka tidak bisa diperdagangkan. Dierickx and Cool (1989) membahas beberapa contoh semacam ini. sumber daya untuk yang hak kepemilikan tidak didefinisikan dengan baik atau dengan masalah kelayakan pembukuan masuk dalam kategori ini (Dierickx and Cool (1989); Meade (1952); Bator (1958)). Begitu juga sumber daya yang langka untuk diperluas bahwa sumber daya tersebut tidak digunakan di luar perusahaan lainnya Williamson (1979). Jenis dari sumber daya lainnya dapat digambarkan sebagai mobilitas yang tidak sempurna. Sumber daya ini adalah sumber daya yang mempunyai kemampuan untuk diperdagangkan akan tetapi lebih berharga berada dalam perusahaan saat ini daripada sumber daya tersebut digunakan di tempat lainnya. Sumber daya yang mobilitasnya tidak sempurna ketika mereka agak khusus untuk kebutuhan perusahaan yang lebih spesifik. Wernerfelt and Montgomery (1988) menggunakan konsep switching costs untuk membahas bagaimana investasi perusahan yang spesifik mepererat hubungan perdagangan antara perusahaan dan pemilik dari faktor-faktor yang digunakan oleh perusahaan. investasi ini oleh pemilik sumber daya dapat dianggap sebagai sunk cost (nonrecoverable cost) yang dapat menghambat faktor yang keluar dari perusahaan. Biaya ini memberikan pertanyaan yang besar bagi.perusahaan pada sumber daya tersebut. Konseptualisasi aset mungkin pada kasus yang lain Teece (1986). Hal ini adalah aset yang harus digunakan dalam hubungannya dengan satu sama lain atau yang memiliki nilai ekonomi yang lebih tinggi ketika digunakan bersama-sama. Sehingga pengguna lain yang sejenis tidak ada yang memiliki ( untuk transaksi yang lebih spesifik) dan untuk mengembangkannya bahwa setidaknya satu dari aset adalah perusahaan yang spesifik, dimana mobilitasnya terbatas. Sumber daya lain mungkin ketidak sempurnaan mobilitas hanya karena biaya transaksi yang terkait dengan transfer sumber daya yang sangat tinggi (Williamson (1979) ; Rumelt (1987a))

Karena sumber daya yang tidak bergerak atau ketidak sempurnaan mobilitasnya adalah sumber daya yang nontradeable atau kurang berharga untuk pengguna lain, sumber daya tersebut tidak bisa ditawarka lagi untuk yang lainnya. Sumber daya tersebut tetap terikat pada perusahaan dan tersedia untuk digunakan dalam jangka panjang. Dengan demikian, sumber daya tersebut dapat menjadi sumber yang unggul dan berkelanjutan. Selain itu, opportunity cost dari penggunaannya adalah kurang signifikan dibandingkan dengani nilai yang digunakan sekarang. Hal ini adalah poin penting dan salah satu yang akan dikembangkan lebih lanjut pada bagian berikutnya. Hal ini juga menyatkan tidak langsung bahwa setiap Ricardian atau monopoly rent yang dihasilkan oleh aset tidak akan diperhitungkan sepenuhnya secara akuntansi sebagai asset dari opportunity cost.

Opportunity cost di sini, dalam arti sedikit berbeda dari penggunaan istilah secara konvensional. Biasanya, hal ini mengacu pada nilai dari sebuah sumber daya dalam penggunaan yang terbaik untuk berikutnya. Di sini, kesungguhan untuk mengacu pada nilai sumber daya untuk kedua-duanya menilai.potensi pengguna yang tertinggi Penggunaan bagi pengguna potensial berharap untuk menempatkan yang sama persis.

Perbedaan antara nilai sumber daya ke perusahaan dan opportunity cost adalah juga merupakan bentuk harga. Harga Pareto, juga disebut harga kuasi, yang merupakan kelebihan nilai aset ini atas penyimpanan atau nilai dalam penggunaan berikutnya yang terbaik. Berikut Klein et al. (1978), menggunakan istilah sepadan dengan harga kuasi atau harga -AQ untuk merujuk pada kelebihan dari nilai aset ini atas nilai kedua tertinggi untuk menghargai pengguna potensial atau penawar sumber daya tersebut.

Klein et al. (1978) menunjukkan bahwa sangatlah mungkin untuk sumber daya menghasilkan harga AQ tanpa adanya baik Ricardian ataupun monopoly rents. Sumber daya tidak perlu langka atau ditiru bagi perusahaan untuk menjadi diferensial yang mungkin berharga untuk pengguna. Dengan demikian kehadiran harga $\mathrm{A}-\mathrm{Q}$ bukan merupakan indikator 
yang cukup untuk keunggulan kompetitif. Harus ada monopoly rent atau Ricardian yang dihasilkan juga.

Harga A-Q yang sepadan dalam arti bahwa harga tidak perlu dibayarkan kepada sumber daya untuk pengguna guna mempertahankan layanannya Klein et al. (1978). Apakah pengguna akan mengunakan seluruh harga $A-Q$, sumber daya dapat diperoleh tidak lebih baik dari tempat lain. Untuk mengetahui bahwa harga akan dibagi antara faktor pemilik dan perusahaan yang menggunkannya. Pertama, salah satu yang mungkin dengan mudah perusahaan melihat dengan keterikatan penggunaan faktor khusus, karena tidak dapat menggantikan faktor generik dengan biaya yang sama. Ini berarti bahwa situasi mungkin ditandai sebagai perdeagangan monopoli yang terbaik, dimana harga distribusi tidak tentu. Kedua, harus mengakui bahwa harga sebenarnya bersamasama diproduksi dan sebanyak factor tersebut untuk perusahaan. Faktor khusus tidak bisa begitu saja sebagai suatu bagian produktif dari perusahaan. Oleh karena itu, yang produktivitas lebih baik disebabkan karena banyak konteks dan unsur-unsur lain dari perusahaan untuk faktor itu sendiri. Perusahaan dan factor-faktor adalah, dalam intinya merupakan suatu tim. Caves (1980) menyatakan bahwa harga tidak sepenuhnya telah dianggap sebagai faktor-faktor yang tidak diperdagangkan di pasar terbuka. Sama dengan Vena, Rumelt (1987a)vena berpendapat bahwa harga pada factor- faktor khusus tidak logis atau operasionalnya dipisahkan dari keuntungan perusahaan' ( hal. 143). Kedua fakta - sumber daya yang mobilitsnya tidak sempurna akan tetap tersedia bagi perusahaan dan bahwa harga akan dibagi oleh perusahaan kunci atas faktor fitur mobilitas tidak sempurna ( lihat Wernerfelt (1989a)). Pada gilirannya, membuat kondisi faktor mobilitas yang sempurna yang diperlukan untuk berkelanjutan keunggulan kompetitif. Selain itu, Faktor mobilitas sempurna adalah komponen model sangat penting karena seperti sumber daya tersebut mungkin kurang imitable daripada jenins-jenis yang lain. Selanjutnya, opportunity cost dari aset tersebut, sebagaimana didefinisikan di atas, tidak diimbangi dengan harga. Tetapi bahkan bersama-sama dengan heterogenitas dan ex post limits to competition, faktor ketidak sempurnaan mobilitas belum cukup untuk berkelanjutan keunggulan kompetitif.

\section{Ex Ante Limits to Competition}

Perusahaan yang ingin memiliki keunggulan kompetitif, keberadaan ex ante limits to competition menjadi keharusan hal ini berarti setiap perusahaan sebelum membangun posisi sumber daya yang unggul, harus membatasi posisi persaingan. Sebuah lokasi yang unggul hanya bisa menjadi sumber pengembalian di atas normal jika beberapa perusahaan memiliki pandangan ke depan untuk mendapatkannya dalam ketiadaan kompetisi. Hal Ini dikemukakan oleh Barney (1986) bahwa dalam kinerja ekonomi perusahaan tidak hanya tergantung pada keuntungan dari strategi mereka, tetapi juga pada biaya pelaksanaan strategi tersebut. Tanpa ketidaksempurnaan dalam faktor strategis pasar, di mana sumber daya yang diperlukan untuk menerapkan strategi adalah mengakuisisi, perusahaan dapat berharap hanya untuk kembali normal. Rumelt (1987a) membuat pandangan yang sama bahwa setidaknya ada perbedaan antara nilai ex post dari usaha dan biaya ex ante untuk memperoleh sumber daya yang diper- lukan, dengan biaya kewirausahaan adalah nol. Keuntungan akan diperoleh dari ketidakpastian ex ante. Sumber daya tradeable yang dapat diperoleh di faktor strategis pasar, argumentasinya dapat diperpanjang untuk bergerak dan ketidak sempurnaan mobilisai sumber daya juga, sebagaimana Dierickx and Cool (1989) dan Barney (1989) telah berpendapat. Ex ante competition untuk mengembangkan ketidak sempurnaan mobilitas sumber daya, seperti goodwill dari klien, dapat juga dengan menghilangkan pengembalian yang diharapkan. Meskipun kecil kemungkinannya bahwa keseluruhan nilai dari sumber daya harus diantisipasi atau bahwa perusahaan akan memiliki efisiensi yang sama dalam mengumpulkan sumber daya, hal penting untuk mengakui bahwa ketidak sempurnaan mobilitas sumber itu sendiri. Harus ada batasan untuk ex ante competition juga.

\section{Pilar keunggulan kompetitif (The cornerstones of competitive advantage)}

Kondisi harus dipenuhi oleh perusahaan untuk berada dalam berkelanjutan di atas pengembalian yang normal. Heterogenitas sumber daya menciptakan Ricardian atau monopoly rent. Ex post limits to competition mencegah harga yang berkompetisi berlalu. Faktor ketidak sempurnaan mobilitas memastikan bahwa faktor yang berharga tetap beada dalam perusahaan dan harganya dibagi. Ex post limits to competition menjaga biaya dari mengambang. Gambar 3 menunjukkan ringkasan modelnya. Model ini dimaksudkan untuk menggarisbawahi masing-masing kondisi yang, berbeda satu sama lain, dan secara eksplisit peran masing-masing dalam menciptakan dan mempertahankan harga. Hal ini tidak dimaksudkan untuk menyiratkan, bagaimanapun, bahwa keempat kondisi adalah sepenuhnya independen satu sama lain. Keempat kondisi tersebut adalah pada kenyataannya terkait. Heterogenitas adalah kondisi yang paling dasar. Itu adalah tindakan yang esensial dari keunggulan kompetitif dan telah lama menjadi konsep dasar strategis manajemen. Untuk alasan ini sepatutnya penekanan khusus. Model ini menggambarkan bahwa heterogenitas diperlukan untuk keuntungan yang berkelanjutan, tetapi tidak cukup memadai. Untuk harga harus dipertahankan, dibutuhkan ex post limits to competition juga. Salah satunya dapat membayangkan heterogenitas tanpa ex post limits to competition. Perusahaan mungkin memiliki usia yang pendek dan tidak berkelanjutan mudah ditiru perbedaannya. Itu membutuhkan memperluas dari imajinasi untuk memahami heterogenitas ex post limits to competition. Untuk sebagian besar, ex post limits to competition menyiratkan heterogenitas, meskipun heterogenitas tidak berarti ex post limit to competition. Heterogenitas mendasari kondisi ketidak sempurnaan mobilitas juga. heterogen sumber daya tidak perlu ketidak sempurnaan mobilitas. Tetapi sulit untuk membayangkan ketidak sempurnaan mobilitas sumber daya yang tidak juga heterogen. Sumber daya yang tidak bisa dipindah-pindahkan karena sifatnya istimewa atau heteroginitas khusus pada perusahaan. Sumber daya yang tidak bisa dipindah-pindahkan karena tidak jelas hak property atau kurangnya pasar yang mungkinkan homogen ( undang-undang pencemaran, misalnya ?) Sekali lagi, mobilitas tidak sempurna, untuk sebagian besar, implikasinya adalah heterogenitas juga.

[Figure 3 about here.] 


\section{Aplikasi Model Berbasis Sumber Daya (Applications of The Resource Based Model)}

Kontribusi utama dari model berbasis sumber daya ( Resource Based Model ) adalah bahwa resource based menjelaskan perbedaan yang berumur panjang dalam profitabilitas perusahaan yang tidak dapat dikaitkan dengan perbedaan kondisi industri. Adanya bukti yang cukup untuk menunjukkan bahwa perbedaan seperti yang tidak dijelaskan dengan baik oleh keterlibatan industri (Schmalensee (1985); Mueller (1986); Wernerfelt and Montgomery (1988); Hansen and Wernerfelt (1989); Rumelt (1991)). Terdapat kesepakatan yang lemah tentang besarnya efek relatif bagi perusahaan, namun beberapa penelitian telah menunjukkan bahwa adanya efek yang substansial (Mueller (1986); Hansen and Wernerfelt (1989); Rumelt (1991)). Model berbasis sumber daya merupakan pelengkap teoritis untuk studi ini. Pada sisi praktis, model dapat membuktikan kegunaannya untuk manajer yang ingin memahami, melestarikan, atau memperpanjang keunggulan kompetitifnya. Sementara model itu sendiri dapat digunakan secara bebas untuk semua, implikasi strategisnya tergantung pada kontribusi sumber daya pada perusahaan secara spesifik. Barney (1986) berpendapat bahwa perusahaan dapat memperoleh keuntungan yang diharapkan dengan menganalisis informasi tentang aset sudah dikendalikan. Selama asetnya adalah tidak mudah dipindah-pindahkan, tidak mudah ditiru, dan tidak dapat diganti, perusahaan lain tidak akan mampu meniru strateginya. Dengan demikian, penerapan model ini tidak akan meningkatkan persaingan untuk ketersediann harga. Strategi ini hanya memastikan bahwa setiap perusahaan yang mengoptimalkan penggunaan sumber daya sendiri yang khusus. Karena fokus pada ketidak sempurnaan mobilitas sumber daya, dimana transaksi biaya dari pertukaran pasar yang tinggi, teori berbasis sumber daya ( resource based theory ) memiliki implikasi penting bagi strategi korporasi ( corporate strategy) dan isu-isu mengenai lingkup perusahaan sebagaimana strategi pada bisnis tunggal ( single business strategy ).

\section{Strategi Bisnis Tunggal (Single business strategy)}

Pada tingkat bisnis tunggal, model dapat membantu manajer membedakan antara sumber daya yang mungkin mendukung keunggulan kompetitif dari sumber daya lainnya yang kurang berharga Barney (1991). Misalnya, sebuah kecerdasan, ilmuwan pemenang hadiah Nobel mungkin sumber daya yang unik, akan tetapi jika memiliki hubungan yang spesifik perusahaan, mobilitas yang sempurna membuatnya sumber ini tidak mungkin memberikan keuntungan yang berkelanjutan. Manajer harus bertanya pada diri sendiri apakah produktivitasnya harus dilakukan, sebagian, dengan Tim peneliti yang spesifik dari mana ia menjadi bagiannya. Apakah itu tergantung pada hubungannya dengan bakat manajer yang sangat mahir dalam mengelola kreativitas ? Apakah itu tergantung pada semangat para pekerja atau budaya yang unik dari perusahaan?. Sebuah perspektif berbasis sumber daya juga dapat membantu perusahaan dalam memutuskan apakah untuk lisensi baru atau apakah teknologi untuk mengembangkan secara internal. Jika teknologi ini dalam artian tidak dapat diindah-pindahkan bahwa nilai potensial yang tidak dapat di dikomunikasikan kepada orang lain karena risiko men- gungkapkan informasi kepemilikan, yang terbaik mungkin dikembangkan secara internal. Alternatifnya, kemampuan pemasaran mungkin bergantung pada aset yang khusus seperti terselenggaranya hubungan dengan vendor yang enggan untuk beralih ke pemasok lain. Jika aset yang khusus ini digunakan oleh perusahaan dan bergerak sendiri, pengembangan internal masih mungkin masuk akal. Jika inovasi mobilitas yang sempurna, inovator bisa melakukan lebih baik daripada untuk lisensi teknologi. Pengambilan keputusan juga akan ditingkatkan dengan mengingat bagaimana inovasi tidak dapat ditiru. Jika inovasi adalah tidak lebih dari sebuah kecerdasan dan tingkat kerumitan yang relative dari ketersedian gabungan teknologi, maka tidak ada pembatas yang bisa menjaga pesaing. Menyadari kerentanan ini, manajer mungkin ingin berpikir lebih hati-hati tentang harapan ketertinggal untuk masuk dan apakah mungkin ada beberapa keuntungan yang dimungkinkan karena perusahaan belajar secara spesifik atau efisiensi aset efisiensi. Kemungkinan pertimbangan untuk mencoba menggunakan mulai berfikir membangun sumber daya yang lebih khusus lainnya yang kurang tersedia (misalnya reputasi untuk layanan pada teknologi baru ). Hal ini mungkin jika sumber sekunder adalah tergantung pada waktu atau jika keuntungan diharapkannya menghambat persaingan dari pengembangan sumber daya sekunder. Dengan menganalisis posisi sumber daya, manajer akan memiliki pemahaman yang jelas apakah situasinya memenuhi kondisi yang diperlukan untuk berkelanjutan keuntungan. Sedikit Kesalahan dari strategis akan terjadi. Tetapi di samping itu, mungkin membantu untuk memanfaatkan keunggulan yang diharapkan untuk masa depan. Amit and Schoemaker (1993) memanfaatkan teori berbasis sumber daya dalam mengembangkan pandangan perilaku strategi aset dan menawarkan beberapa preskriptif saran tentang bagaimana target, mengembangkan dan menyebarkannya. Wernerfelt (1989b) mengusulkan beberapa pedoman untuk membantu manajer mengidentifikasi sumber daya kritis mereka dan memutuskan bagaimana untuk menerapkannya. Dalam beberapa kasus kausal ambiguitas dapat membuatnya memungkinkan bagi perusahaan untuk mengevaluasi sumber daya atau bahkan untuk mengidentifikasinya. (Lihat Lippman and Rumelt (1982)). Sementara sumber daya tersebut dapat menjadi dasar untuk keunggulan kompetitif, kausal ambiguitas terlibat meninggalkan sedikit ruang untuk strategi. Kepemilikan sumber daya perusahan tidak mempunyai keunggulan informasi lebih dari perusahaan lain dan sedikit kemampuan untuk memanfaatkan sumber daya lebih lanjut karena adanya ketidakpastian mengenai dimensi dan/ atau nilainya. Sumber daya lainnya dapat lebih mudah diidentifikasi sebagai penciptaan nilai sumber daya, namun reproduksinya mungkin sangat tidak pasti. Sumber daya yang sangat tergantung pada waktu atau yang secara sosial kompleks akan sesuai dengan kategori ini. (Lihat Barney (1991)) Sementara sumber daya dapat susah untuk mereproduksi atau memperpanjang, kepemilikian asset perusahaan adalah cenderung memiliki keuntungan yang kuat dalam memperluas dibandingkan perusahaan lain. Keunggulan ini adalah informasional, berbasis pada kerumitan, dan pemahaman secara diam-diam, dan tidak mudah diakses oleh pihak luar. Tetapi juga karena produksi sumber daya sosial secara kompleks yang mungkin memerlukan asset perusahaan yang lebih khusus tidak dapat diduplikasi dalam pen- 
gaturan lainnya. Pandangan berbasis sumber daya akan membantu manajer untuk memahami bahwa sumber daya tersebut dapat menjadi landasan penting bagi keunggulan kompetitif. Dan, dengan menyoroti nilai sumber daya, mungkin membantu manajer melihat bahwa, meskipun kesulitan, mereka harus mempertimbangkan memanfaatkan sumber daya lebih lanjut.

\section{Corporate Strategy}

Model berbasis sumber daya secara fundamental berkaitan dengan akumulasi aset internal, dengan spesifisitas aset, dan, berhubungan tidak langsung dengan biaya transaksi. Oleh karena itu, secara natural cocot untuk mempertimbangan pertanyaan mengenai batas-batas perusahaan. Sejumlah peneliti telah memanfaatkan pandangan berbasis sumber daya untuk menganalisis isu-isu mengenai ruang lingkup perusahaan.

Barney (1988), misalnya, telah membahas masalah apakah penawaran yang dilakukan perusahaan menyadari kembali mungkin tidak normal dari akuisisi strategis yang terkait. Kerangka berbasis sumber daya menyediakan jawaban bahwa hal itu tergantung pada seberapa langka dan kemudahan untuk ditiru adalah kombinasi yang dihasilkan dari sumber daya. Montgomery and Hariharan (1991), telah menunjukkan bahwa perusahaan dengan basis sumber daya yang luas cenderung untuk mengejar diversifikasi. (Lihat Penrose (1959)). Dengan demikian, perusahaan cenderung untuk memasuki pasar dimana kebutuhan sumber daya sesuai dengan kemampuan sumber dayanya. Teori diversifikasi yang berlaku dapat karakteristikan sebagai berbasis sumber daya ( resource based ). (Lihat, misalnya, Teece (1982a); Wernerfelt (1984b), Williamson (1985); Wernerfelt and Montgomery (1986); Montgomery and Wernerfelt (1988a)). Teori ini mencirikan jenis sumber daya yang mendukung diversifikasi sebagai quasi yang tetap, namun belum sepadan secara inheren : yaitu, dapat mendukung berbagai produk. Sumber daya lain dapat memiliki properti dari barang-barang publik, dalam penggunaannya menjadi satu aplikasi tanpa mengurangi ketersediaannya untuk keperluan lain. Sebuah nama merek ( brand merk ), misalnya, dapat digunakan tanpa mengunakan yang dalam proses. Inti dari teori ini adalah bahwa diversifikasi merupakan hasil dari kelebihan kapasitas sumber daya yang memiliki kegunaan ganda dan yang ada kegagalan di pasar.Tanpa kegagalan pasar, selama biaya transaksi yang tinggi atau tidak dapat dipindah-pindahkan, perusahaan hanya bisa menjual jasa sumber dayanya yang berlebihan. Dalam hal ini, satu perusahaan bisnis dapat beroperasi secara lebih efisien dari sebuah perusahaan yang terdiversifikasi, bahkan jika ada economies of scope (Teece (1980b); Teece (1982b) ). Salah satu isu, yang telah memadai dtunjukkan adalah paradoks bagaimana ' kelebihan kapasitas' sumber daya dapat menyebabkan harga kelangkaan untuk pemegang sumber daya. Tentu saja, gagasan ini yang kompatibel jika memiliki sumber daya tetapi penggunaan tunggal, karena sumber daya rendah akan tersingkir dari yang pasar (lihat Gambar 2). Ingat, bagaimanapun, bahwa harga sumber daya ditentukan oleh kondisi penawaran dan permintaan di faktor pasar. Faktor permintaan, pada gilirannya, berasal dari tuntutan dari semua produk yang dapat digunakan untuk memproduksi. Jika, pada harga ekuilibrium, Faktor heterogen diperlukan di seluruh pasar, maka faktor yang unggul akan mendapatkan harga, terlepas dari apakah melampaui ketersediaan kebutuhan pasar produk tunggal. Itu semua adalah masih langka dibandingkan dengan kebutuhan total penggunaannya. Dengan cara ini kapasitas, kelebihan sumber daya dalam pasar produk tunggal yang kompatibel dengan kemampuan untuk memerintahkan harga kelangkaan. Demikian pula, sumber daya dengan karakteristik barang publik dapat mendapatkan harga, meskipun ketersediaan untuk beberapa pekerja. Karena, setelah beberapa titik, terdapat batasan untuk perluasan sumber daya, mungkin karena pasokan asset yang sangat khusus tetap dalam perusahaan, sumber daya tersebut mungkin masih relatif langka terhadap total permintaan untuk layanannya. Eastman Kodak adalah contoh perusahaan yang telah melakukan diversifikasi atas dasar kelebihan kapasitas kemampuan intinya dalam teknologi fotografi. Kemampuannya untuk memperluas di pasar tertentu adalah dibatasi oleh pangsa pasar yang tinggi dan pertimbangan antitrust. Pada pertengahan tahun 70-an, pangsa pasar untuk film diperkirakan sebesar 90 persen ; itu diperkirakan sebesar 85 persen untuk kamera. Untuk lebih memanfaatkan yang tak terhingga R \& D kemampuan Kodak harus mencari peluang di luar pasar asli perusahaannya. Hal ini dimungkinkan karena potensi aplikasi teknologi fotografi cukup luas, meliputi film dan peralatan, medis dan industri film Xray dan peralatan-peralatan, produk audiovisual, mikrofilm, dll. Pada tahun 1975, Kodak memiliki pasar saham hanya 38 persen dari keseluruhan pasar A.S untuk produk fotografi amatir. Dalam pengertian ini, sumber daya yang relatif langka terhadap total permintaan untuk penggunaannya atas semua aplikasi, meskipun kelebihan relatif kapasitas terhadap pasar tertentu. Masalah lain yang perlu perhatian lebih lanjut adalah pertanyaan mengapa perusahaan tidak berkembang sepenuhnya di permulaan pasar sebelum masuknya pesaing. Kemungkinan bahwa model kompetitif memadai untuk mengkarakterisasi pasar produk. Atau mungkin bahwa, secara umum, baik sumber daya dan kondisi pasar lebih baik diwakili dalam model dinamis, yang berubah secara bertahap Montgomery and Hariharan (1991). Montgomery and Wernerfelt (1988b), menggunakan kerangka kerja yang menjadi ciri sumber daya dengan kekhususan atau berbagai aplikasi. Diversifikasi dipandang sebagai hasil dari pencocokan sumber daya perusahaan untuk mengatur peluang pasar. Kedua kondisi ini bersamasama menentukan baik sebagai pilihan strategis dan profitabilitas dari suatu perusahaan. Misalnya, kekhususan keahlian tinggi dalam teknologi kaca akan membatasi suatu perusahaan dari diversifikasi atas dasar sumber daya ini. Dan, karena sumber daya khusus juga cenderung relatif langka, model akan memprediksi harga lebih tinggi untuk diversifiers yang sempit. Sebaliknya, perusahaan-perusahaan dengan sumber daya yang digeneralisasikan mungkin menghadapi pengaturan kesempatan yang lebih luas. Jadi, sebagai contoh, sebuah perusahaan dengan keahlian dalam pemotongan biaya, diwujudkan dalam tim manajer dan rutinitas perusahaan yang khusus, mungkin diversifikasi cukup luas. Harga yang lebih rendah diharapkan, namun, karena keterampilan ini mungkin lebih besar penawarannya. Hal ini tidak berarti bahwa tidak ada nilai kelangkaan sumber daya, tetapi hanya bahwa sumber daya yang relatif kurang langka daripada yang lebih khusus. Pentingnya adalah bahwa manajerial sumber daya yang heterogen, manajer heterogen dan kurang unggul dari yang tidak 
dapat dipindah-pindah. Walaupun penulis tidak mengatakan demikian, model juga menyiratkan bentuk optimalisasi diversifikasi. Karena, pengembalian di setiap penambahan pasar berkurang karena kehilangan efisiensi sumber daya, diversifikasi akan berhenti ketika harga di pasar ditambah yang akhirnya adalah nol.

[Figure 4 about here.]

Dosi et al. (1990) membahas isu tingkat keterkaitan antara produk perusahaan yang mereka sebut koherensi dalam setiap kegiatan usaha. Para penulis memanfaatkan konsep dari organisasi ekonomi untuk menjelaskan hubungan antara kompetensi inti perusahaan dan derajat koherensi di antara bagian-bagiannya. Menurut teori ini, variasi kecepatan pembelajaran, luasnya dependensi, tingkat spesialisasi aset dan sifat dasar dari seleksi lingkungan menjelaskan sifat dan luasnya ruang lingkup perusahaan. Karya ini, meskipun awal, tampaknya membuat sangat bermanfaat dipermulaan. Selain itu, hal ini menyoroti kekayaaan yang mungkin penggunaannya dibuat dari evolusi ekonomi, khususnya, menjelaskan alasan fenomena pusat kepentingan untuk peneliti mengambil pandangan strategi berbasis sumber daya. Teori berbasis sumber daya ( resource based theory ), secara jelas, memiliki kekuatan dan implikasi untuk pertanyaan penting yang berkaitan dengan lingkup perusahaan. Hal ini adalah teori pemersatu yang memungkinkan untuk melihat kedua diversifikasi terkait dan tidak terkait melalui pandangan yang sama. Diversifikasi ini ditujukan untuk jangkauan serta jenis. Lebih jauh lagi perbandingan teori ini secara bersamaan menjelaskan perbedaan profitabilitas yang diamati di seluruh perusahaan, sementara juga menawarkan penjelasan tentang mengapa semua perusahaan tidak dan tidak dapat mengejar strategi yang secara agregat menawarkan pengembalian yang tertinggi. Sebaliknya, perusahaan dipandang mengadopsi strategi yang dapat mendukung sumber dayanya. Sama seperti semua sumber daya yang mendukung strategi bisnis tunggal tidak memiliki kesamaan potensi untuk mengenerate laba, juga tidak berbagai. sumber daya pendukung sebagai strategi diversifikasi Untuk perusahaan individu, apakah itu adalah bisnis singleline atau diversifikasi luas, tugas pentingnya adalah dengan menggunakan sumber daya yang tersedia terbesarnya dapat mendukung sampai akhir.

\section{Peluang dan Tantangan Revolusi Industri 4.0}

Revolusi industry 4.0 merupakan revolusi industri generasi ke4 memiliki skala, ruang lingkup dan kompleksitas yang lebih luas. Kemajuan teknologi baru yang mengintegrasikan dunia fisik, digital dan biologis telah mempengaruhi semua disiplin ilmu, ekonomi, industri dan pemerintah. Perkembangan ilmu pengetahuan dan teknologi yang semakin pesat pada awal abad 20 telah melahirkan teknologi informasi dan proses produksi yang dikendalikan secara otomatis. Mesin industri telah menggunakan sistem otomatisasi berbasis komputer, tidak lagi dikendalikan oleh tenaga manusia, hal ini berdampak pada biaya produksi menjadi semakin murah seiring teknologi informasi yang terus bergerak maju. Revolusi industri mengalami puncaknya saat ini dengan lahirnya teknologi digital yang berdampak masif terhadap hidup manusia di seluruh dunia. Revolusi industri terkini atau generasi keempat mendorong sistem otomatisasi di dalam semua proses aktivitas. Teknologi internet telah menjadi basis bagi transaksi perdagangan dan transportasi secara online. Aplikasi media sosial, bioteknologi dan nanoteknologi semakin menegaskan bahwa dunia dan kehidupan manusia telah berubah secara fundamental. Revolusi industry 4.0 telah membawa perubahan seperti persaingan antara taksi konvensional versus taksi online atau ojek pangkalan vs ojek online, Semua itu pada akhirnya berdampak kepada public, yang diuntungkan dengan untuk mendapatkan layanan transportasi dengan harga yang terjangkau. Teknologi online telah membawa perubahan yang besar terhadap peradaban manusia dan ekonomi. Revolusi industry 4.0 membuka peluang yang luas untuk maju dan informasi yang bermanfaat untuk pengembangan ilmu pengetahuan maupun perekonomian. Masyarakat di era revolusi industry 4.0 memiliki ketergantungan yang sangat besar dalam menggunakan teknologi informasi. Fakta yang menunjukkan bahwa masyarakat memiliki tingkat ketergantungan yang tinggi pada perangkat ponsel pintarnya. Hal ini dapat menjadikan munculnya sebuah peluang baru di era industry 4.0. Salah satu diantaranya adalah peluang berbisnis era digital, daya jangkau teknologi informasi dengan skala global yang dapat dijangkau hingga ke berbagai penjuru dunia. Peluang lain diantaranya adalah saat setiap orang memiliki akses yang tinggi untuk terlibat aktif untuk memberikan dan membagikan opini kepada pihak lain melalui media sosial online. Situasi ini membuka peluang bagi masyarakat untuk membentuk opini positif tentang berbagai hal kepada pihak lain. Kemampuan seseorang untuk mengolah pengetahuan ( knowledge ) menjadi kearifan ( wisdom ) dalam lingkungan sosialnya akan menentukan tingkat ketahanannya di era informasi. Revolusi industri 4.0 tidak hanya menyediakan peluang, tetapi juga tantangan bagi generasi milineal. Kementerian Tenaga Kerja ( Kemnaker ) dalam Kompas.com, Selasa (24/4/2018), menyatakan bahwa akan ada jenis pekerjaan yang hilang seiring berkembangnya revolusi industri 4.0. Direktur Jenderal ( Dirjen ) Pembinaan, Pelatihan, dan Produktivitas Kemnaker Bambang Satrio Lelono menyampaikan, sebanyak 57 persen pekerjaan yang ada saat ini akan tergerus oleh robot, tetapi akan muncul beberapa pekerjaan baru yang jumlahnya diprediksi sebanyak 65.000 pekerjaan. Untuk dapat beradaptasi dengan perubahan revolusi industri 4.0, harus memiliki kemampuan yang tidak akan bisa dilakukan oleh mesin. Soft skill adalah kunciny. Untuk dapat menghadapi perubahan pada tahun-tahun mendatang, dibutuhkan para pekerja yang memiliki soft skill seperti diantaranya pemecahan masalah yang komplek, berpikir kritis, kreativitas, manajemen manusia, berkoordinasi dengan orang lain, kecerdasan emosional, penilaian dan pengambilan keputusan, berorientasi servis, negosiasi, dan fleksibilitas kognitif, artinya, soft skill menjadi salah satu faktor paling penting untuk dimiliki para pekerja di masa depan, seperti kemampuan berkomunikasi dan bekerja sama dengan orang lain, memecahkan masalah, serta aspek kecerdasan emosional lainnya. Pada umumnya, industri menekankan kebutuhan akan karyawan yang bisa terus belajar, cepat beradaptasi dan melek teknologi.Sitem pendidikan juga menekankan pengembangan soft skill, selain keterampilan teknis, generasi milenial ke depan bisa lebih mampu beradaptasi secara cepat terhadap perubahan dan memiliki bekal mumpuni untuk menghadapi masa depan dan pengembangan 
karirnya di tengah munculnya revolusi industri 4.0

\section{KESIMPULAN}

Teori ini muncul untuk membuktikan paradigma yang mampu menjelaskan dan mengintegrasikan penelitian di semua bidang strategi. Meskipun perlu untuk bekerja lebih lanjut, namun telah menunjukkan hasilnya untuk menjadi alat yang kuat dan integratif. Memiliki implikasi kuat untuk single- strategi bisnis, untuk strategi perusahaan, untuk teori dan praktisi. Yang penting, adalah satu-satunya teori dari lingkup perusahaan yang mampu menjelaskan berbagai diversifikasi, dengan segala kekayaannya, tidak dibatasi terkait untuk bentuk konglomerat. Ini adalah tanda yang penting dari teori diversifikasi yang kuat Teece (1982a). Ini adalah bidang yang sudah siap untuk penelitian, yang telah menunjukkan hasil dan layak sebagai upaya terkonsentrasi dari komunitas pembelajar.

\section{REFERENCES}

Amit, R. and Schoemaker, P. J. (1993). Strategic assets and organizational rent Strategic Management Journal 14, 33-46.

Andrews, K. R. (1971). The Concept of Corporate Strategy (Irwin, Homewood, IL).

Bain, J. (1956). Barriers to New Competition (Cambridge, MA: Harvard University Press)

Barney, B. (1989). Asset stocks and sustained competitive advantage: A comment Management Science 35, 1511-1513.

Barney, J. B. (1986). Strategic factor markets: Expectations, luck and business strategy. Management Science 42, 1231-1241.

Barney, J. B. (1988). Returns to bidding firms in mergers and acquisitions: Reconsidering the relatedness hypothesis. Strategic Management Journal 9, 71-78.

Barney, J. B. (1991). Firm resources and sustained competitive advantage. Journal of Management 17, 99-120.

Bator, F. (1958). The anatomy of market failure. Quarterly Journal of Economics, 351-379.

Castanias, R. and Helfat, C. (1991). Managerial resources and rents. Journal of Man agement $17,155-171$

Caves, R. E. (1980). Industrial organization, corporate strategy and structure'. Journal of Economic Literature 18, 64-92.

Caves, R. E. and Porter, M. (1977). From entry barriers to mobility barriers: Conjec tural decisions and contrived deterrence to new competition. Quarterly Journa of Economics 91, 241-262.

Connor, K. (1991). A historical comparison of resource-based theory and five schools of thought within industrial organization economics: Do we have a new theory of the firm? Journal of Management 17, 121-154.

Dierickx, I. and Cool, K. (1989). Asset stock accumulation and sustainability of competitive advantage. Management Science 35, 1504-1511.

Dosi, G., Teece, D., and Winter, S. (1990). 'Toward a theory of corporate coherence: Preliminary remarks', . Working paper.

Ghemawat, P. (1986). 'Sustainable advantage'. Harvard Business Review, 53-58. Sustainable advantage.

Hansen, G. and Wernerfelt, B. (1989). Determinants of firm performance: The relative importance of economic and organizational factors. Strategic Management Journal 10, 399-411.

Klein, B., Crawford, R., and Alchian, A. (1978). Vertical integration, appropriable rents, and the competitive contracting process. Journal of Law and Economics 21, 297-326.

Lippman, S. A. and Rumelt, R. P. (1982). Uncertain imitability: An analysis of interfirm differences in efficiency under competition. The Bell Journal of Economics $13,418-438$.

Mahoney, J. and Pandian, J. R. (1992). The resourcebased view within the conversation of strategic management. Strategic Management Journal 13, 363-380.

Meade, J. (1952). External economies and diseconomies in a competitive situation. Journal of Economic Behavior, 71-89. Economic Journal.

Montgomery, C. A. and Hariharan, S. (1991). Diversified expansion by large established firms. Journal of Economic Behavior, 71-89.

Montgomery, C. A. and Wernerfelt, B. (1988a). 'Diversification, Ricardian rents, and Tobin's q'.

Montgomery, C. A. and Wernerfelt, B. (1988b). Diversification, Ricardian rents, and Tobin's q.

Mueller, D. (1986). Profits in the Long Run (Cambridge, MA: Cambridge University Press).

Nelson, R. R. and Winter, S. G. (1982). An Evolutionary Theory of Economic Change (Cambridge, MA: Belknap Press).

Penrose, E. T. (1959). The Theory of Growth of the Firm (Basil Blackwell, London).

Porter, M. E. (1980). Competitive Strategy: Techniques for Analyzing Industries and Competitors (The Free Press).

Prahalad, C. K. and Hamel, G. (1990). The core competence of the corporation. Harvard Business Review, 79-91.

Rumelt, R. P. (1984a). Toward a strategic theory of the firm. In Competitive Strategic Management, ed. R. L. . (Prentice Hall), 55-570.

Rumelt, R. P. (1984b). Toward a strategic theory of the firm. In Competitive Strategic Management, ed. R. L. . (Prentice Hall), 55-570.

Rumelt, R. P. (1987a). Theory, strategy, and entrepreneurship. In The Competitive Challenge, eds. D. T. . and . 137-158.

Rumelt, R. P. (1987b). Theory, strategy, and entrepreneurship. In The Competitive Challenge, eds. D. T. . and . 137-158

Rumelt, R. P. (1991). How much does industry matter? Strategic Management Journal 12, 167-186.

Schmalensee, R. (1985). Do markets differ much? The American Economic Review $75,341-350$.

Teece, D. J. (1980a). Economies of scope and the scope of the enterprise'. Journal of Economic Behavior and Organization 1, 223-247.

Teece, D. J. (1980b). Economies of scope and the scope of the enterprise'. Journal of Economic Behavior and Organization 1, 223-247.

Teece, D. J. (1982a). Toward an economic theory of the multiproduct firm. Journal of Economic Behavior and Organization 3, 39-63.

Teece, D. J. (1982b). Toward an economic theory of the multiproduct firm. Journal of Economic Behavior and Organization 3, 39-63.

Teece, D. J. (1986). Firm boundaries, technological innovation, and strategic management'. In L. G. Evolutionary Theory of Economic Change (Cambridge, MA: Belknap Press)

Thompson, A. A. and Strickland, A. J. (1990). Strategic Management: Concepts and Cases (Irwin, Homewood, IL).

Wernerfelt, B. (1984a). A resource based view of the firm. Strategic Management Journal 5, 171-180.

Wernerfelt, B. (1984b). A resource based view of the firm. Strategic Management Journal 5, 171-180.

Wernerfelt, B. (1989a). From critical resources to corporate strategy. Journal of General Management 14, 4-12.

Wernerfelt, B. (1989b). From critical resources to corporate strategy. Journal of General Management 14, 4-12.

Wernerfelt, B. and Montgomery, C. A. (1986). What is an attractive industry? Management Science 32, 1223-1229.

Wernerfelt, B. and Montgomery, C. A. (1988). Tobin's q and the importance of focus in firm performance. American Economic Review 78, 246-250.

Williamson, . E. (1979). Transaction-cost economics: The governance of contractual relations. Journal of Law and Economics 22, 233-261.

Williamson, . E. (1985). The Economic Institutions of Capitalism (New York: Free Press).

Yao, D. (1988). Beyond the reach of the invisible hand: Impediments to economic activity, market failures, and profitability. Strategic Management Journal 9, 59-

Conflict of Interest Statement: The authors declare that the research was conducted in the absence of any commercial or financial relationships that could be construed as a potential conflict of interest.

Copyright (c) 2019 Hertina and Hidayat. This is an open-access article distributed under the terms of the Creative Commons Attribution License (CC BY). The use, distribution or reproduction in other forums is permitted, provided the original author(s) and the copyright owner(s) are credited and that the original publication in this journal is cited, in accordance with accepted academic practice. No use, distribution or reproduction is permitted which does not comply with these terms. 


\section{LIST OF FIGURES}

1 Scarcity rents withheterogeneous factors Key: $\mathrm{P}^{\star}=$ Equilibrium Price, $=$ Rents to Eficient Producer . . . . . . 116

2 Imitation (expansion) of low cost firmcauses rents to dispate and hight-cost firms to exit Key: $\mathrm{P}^{\star *}=$ New Equilib-

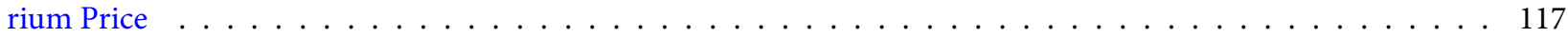

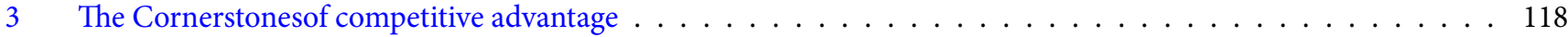

4 The determination of the extent of diversification Key; $\mathrm{D}^{*}=$ Extentof Diversification, = Accumulated Rents . . . 119 


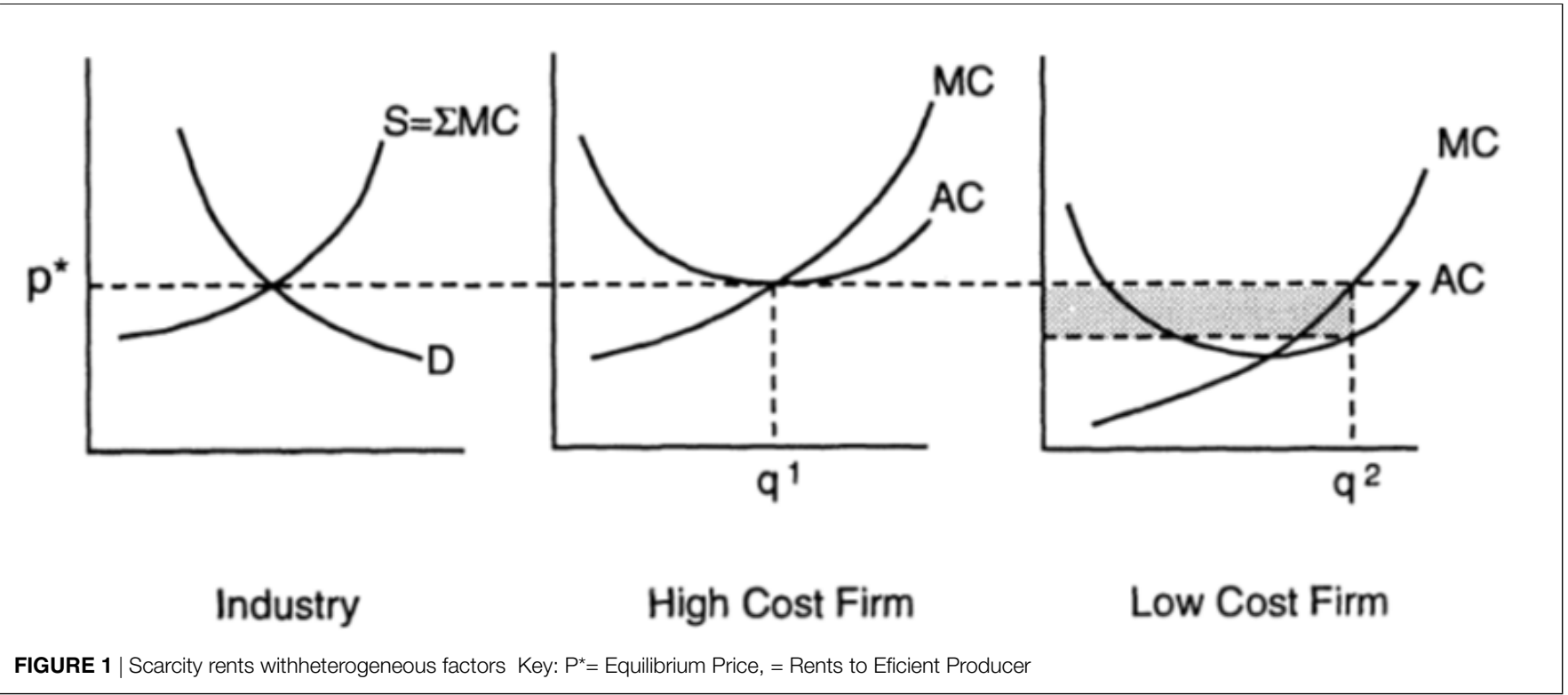




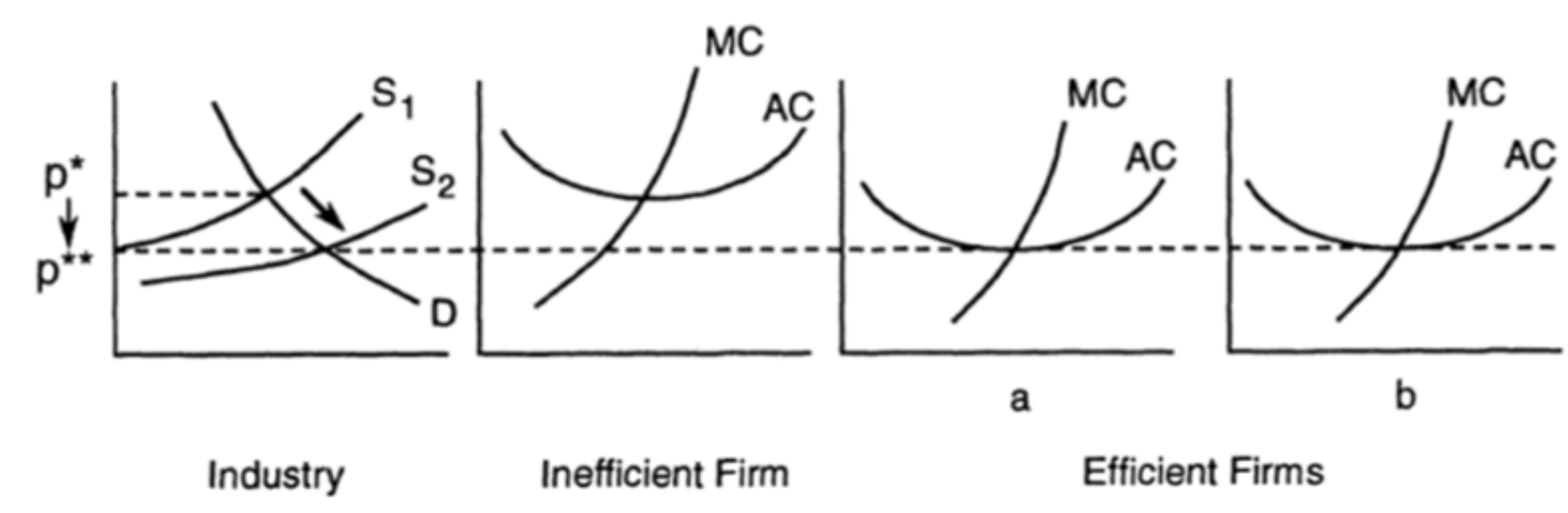

FIGURE 2 | Imitation (expansion) of low cost firmcauses rents to dispate and hight-cost firms to exit Key: $\mathrm{P}^{\star \star}=$ New Equilibrium Price 


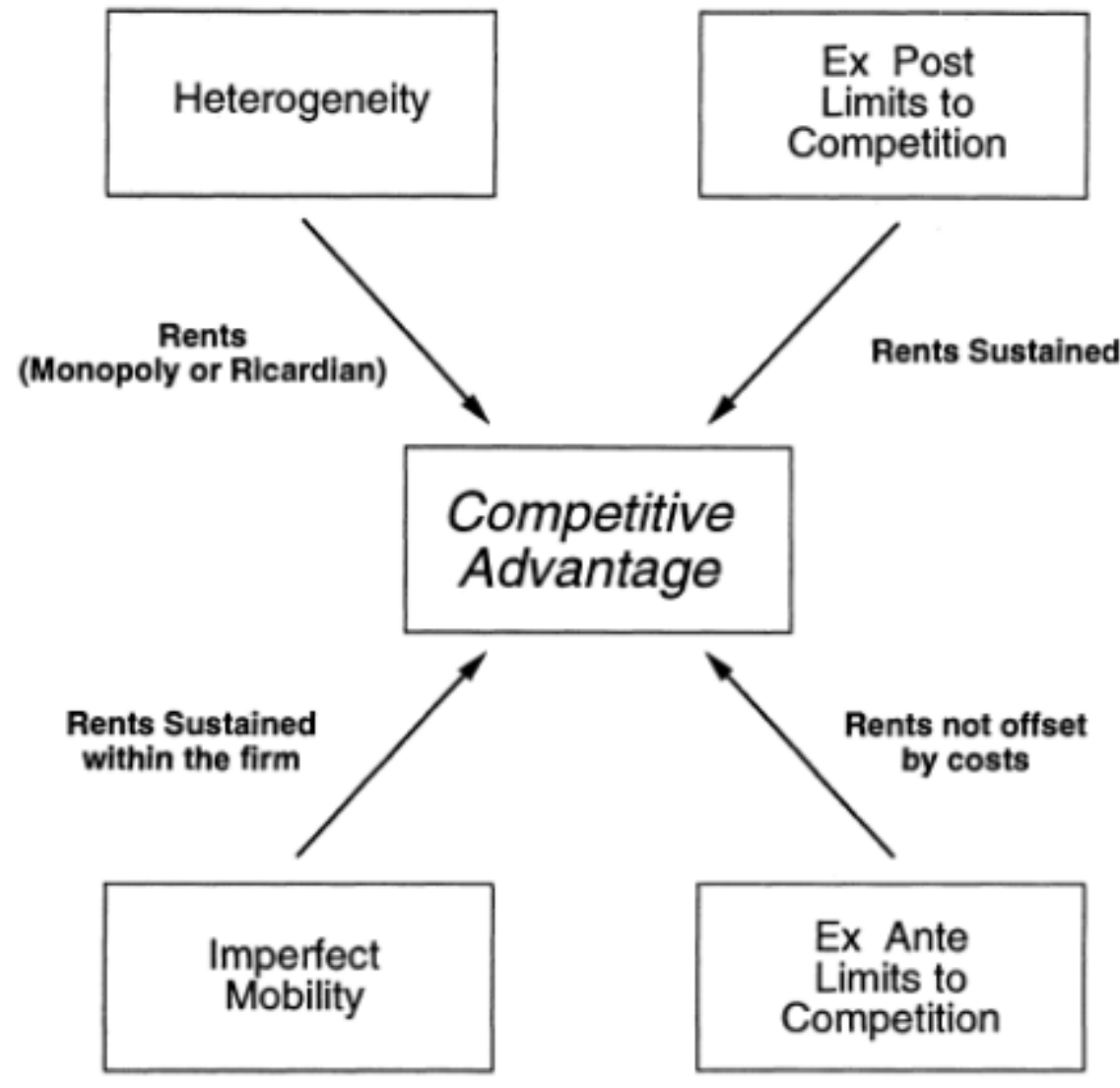

FIGURE 3 | The Cornerstonesof competitive advantage 


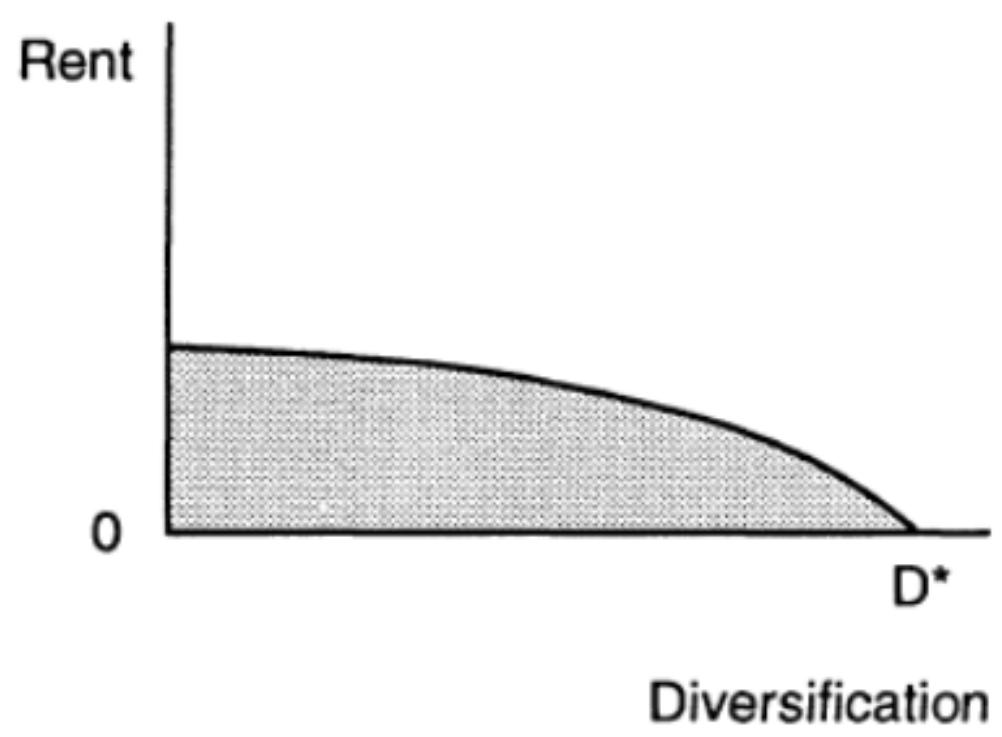

FIGURE 4 | The determinationof the extent of diversification Key; D* = Extentof Diversification, = Accumulated Rents 